\title{
Kondorosi Ferenc - Sereg András (szerk.): Noé galambja - Megjavul-e az emberiség a járvány után?
}

\section{LIPPAI Zsolt ${ }^{1 \oplus}$}

\section{(Budapest, Bíbor, 2020)}

A Földön 2021. május 12-én 18:43 órakor pontosan 7865261573 ember él, ${ }^{2}$ amelyből a koronavírus következtében világszerte 160758949 a fertőzöttek, 3337886 az elhunytak és 138537155 a gyógyultak száma. ${ }^{3}$ Magyarország kormánya által az új koronavírus elleni küzdelem érdekében létrehozott operatív törzs adatai szerint hazánkban 4391794 fös beoltottság mellett 172456 honfitársunk aktív fertőzött, 592440 gyógyult meg, és 28878 ember hunyt el. ${ }^{4}$ Ugyanakkor, e könyvismertetés megírásakor a PubMed ${ }^{5}$ adatbázisában - amely valószínúleg a világ legnagyobb multidiszciplináris tudományos adatbázisa - 133120 olyan tudományos publikáció lelhető fel, amelynek címében vagy összefoglalójában előfordul a Covid-19 kifejezés. Tekintve, hogy az első ilyen témájú tanulmány 2020 márciusában jelent meg, 14 hónap alatt a vírus eredményeként havonta több mint 9500, a Covid-19-cel foglalkozó lektorált, tudományos igényességgel elkészített írásmú látott napvilágot. További különösen érdekes és véleményem szerint igen nehezen megbecsülhető szám lehetne a különböző írott és elektronikus híradásokban megjelent cikkek, blogok, kommentek, posztok, városi legendák száma. Ezáltal nyugodt szívvel jelenthetem ki, hogy a nagyszámú emberéletet követelő - a közép-kínai Hupej tartományának székhelyén, Wuhan városában 2019 decemberében felfedezett -, új típusú koronavírus (SARS-CoV-2), amelyet az Egészségügyi Világszervezet (WHO) 2020. március 11-én világjárvánnyá nyilvánított, nagymértékben megmozgatta a tudományos világ írástudóit, és közvetlenül vagy közvetve, talán valamennyi embertársunk életére is rendkívüli hatást gyakorolt. ${ }^{6}$

\footnotetext{
Lippai Zsolt r. alezredes, Nemzeti Közszolgálati Egyetem Rendészettudományi Kar Magánbiztonsági és Önkormányzati Rendészeti Tanszék, mesteroktató, Rendészettudományi Doktori Iskola, doktori hallgató.

Zsolt Lippai, Police Lieutenant Colonel, University of Public Service, Faculty of Law Enforcement, Department of Private Security and Local Governmental Law Enforcement, Assistant Lecturer, Doctoral School of Police Sciences and Law Enforcement, PhD student. E-mail: lippai.zsolt@uni-nke.hu

Worldometers: Current World Population.

Worldometers: Covid-19 Coronavirus Pandemic.

Tájékoztató oldal a koronavírusról: https://koronavirus.gov.hu/\#/

National Center for Biotechnology Information: https://pubmed.ncbi.nlm.nih.gov/?term=covid+19.

Lippai Zsolt - Kacvinszki Blanka: A „másképp lesz holnap” ígérete. Belügyi Szemle, 69. (2021), 2. 93-104.
} 
A világjárvánnyal kapcsolatos egyik domináns álláspont szerint, a világunk már soha nem lesz olyan, mint ahogyan eddig volt, a vírus nagy változásokat hozott és még hoz is az életünkben. Ezért (is) különösen értékes alkotás a jelen recenzió tárgyát képező, Kondorosi Ferenc és Sereg András szerkesztésében 2020-ban - a Bíbor Kiadó gondozásában - megjelent „Noé galambja, Megjavul-e az emberiség a járvány után?” címú, a világjárvány hatásait vizsgáló tanulmányokat befoglaló könyv.

A tanulmánykötet előszavában Dr. Janza Frigyes ny. r. vezérőrnagy c. egyetemi tanár BM Oktatási Főszemlélő, a cím bibliai eredetű galambhasonlatának magyarázatát követően mutat rá, „ez a könyv kezdeti lépés a globalizált világ által létrehozott önpusztító veszélyek elleni szellemi összefogást meghaladó cselekvések számbavételéhez”. A kötet szerzői pedig e gondolat mentén, személyes világképük tükrében adnak lelki erőt, hogy higgyünk a közös cselekvés erejében.

Dr. Beer Miklós nyugalmazott váci megyés püspök Noé galambja című, teológiai tanulmányában állapítja meg, az emberiségnek talán még soha nem volt ekkora lehetősége arra, hogy ilyen mélységben tegye fel a kérdést, vajon jó úton jár-e? Életünk apró csodáit sorolva bizonyítja, ez a világrend ilyen, amellyel egy másik világrend ígéretét is kaptuk, szembesítve az emberiséget azzal, hogy beképzeltségünk, önteltségünk felborította a természetes egyensúlyt. Sebzett és beteg világunkban hittel kell vállani a megpróbáltatásokat, szelíden, de következetesen kell példát mutatni, várva a címadó galambot az olajággal, azzal a hírrel, hogy valóban újraindult az élet, és már nem a „régi kovásszal élesztjük a kenyeret”.

Dr. Haller József tanszékvezető egyetemi tanár A félelem vírusa írásában az elhalálozási területek súlypontjait vizsgálva, a vírussal kapcsolatos információhiány, dezinformációk és összeesküvés-elméletek útján foglalja össze, hogy a járvány kitörésének és lefolyásának minden szociális körülménye - sok esetben indokolatlan méretű szorongássá fokozódó - félelmet keltett. További érdekes tényként állapítja meg, hogy a mentális egészség romlása nem kötődik szorosan a vírusfertőzéshez, mert az a meg nem fertőzötteknél is tapasztalható volt, ugyanakkor a zavar tartósságára való tekintettel a poszttraumásstressz-zavar aggasztó gyakorisága is megnőtt.

Horváth László kultúrakutató A posztcovid világ cikkében a világjárvány hatásainak eltúlzott értékelését bizonyítja, véleménye szerint ugyanis sokkal érdekesebb dolog a nagy változások mellett érvelni és egy átalakult világ eljövetelét hirdetni, mint a dolgok folytonossága mellett bizonyítékokat felsorakoztatni. A járvány három szakaszát megkülönböztetve, annak antropológiai és társadalmi feltételeit, a közemlékezet működését és a szükségletek inerciáját elemezve a járványt mint a közbizalmat nem erősítő jelenkortörténetet mutatja be.

Dr. Kelemen Gábor egyetemi tanár Járvány és válság fejezetének már az elején kijelenti, a Covid-19-betegséggel való küzdelem közvetlen tétje az emberiség idős és meggyengült immunrendszerủ rétegének a vírus által okozott haláltól történő megmentése, távlati célja pedig a kórokozó likvidálása, visszatérésének megakadályozása. A vírus egészségügyi aspektusból, számos történeti példával elemzett 
bemutatásának különösen érdekes színt ad Alkmaión tanításával képzett párhuzama, a politika biologizálására való utalása. Annak magyarázata, amely szerint, bár a Covid-19 természetadta jelenségként ütötte fel a fejét, a nemzetállamok által deklarált járványügyi válsághelyzet társadalmi és gazdasági következményei erősebbnek látszanak, mint maga a járvány.

Dr. Kondorosi Ferenc egyetemi tanár A kockázat fogsága tanulmánya, Ferenc pápa Laudato si, azaz Áldott légy kezdetű közös otthonunk gondozásáról szóló enciklikájának gondolataival világít rá arra, hogy Földünkön nem pusztán a természeti környezet vesz körül bennünket, hanem az emberi környezet is. Értelmezi a fenntartható fejlődés három alappillérét, a szociális, a gazdasági és a környezeti szempontok együtthatását. Az emberiség fejlődése szempontjából, a járvány által hangsúlyosabbá vált kritikus tényezők megjelölésével, pesszimista szemlélőként hívja fel a figyelmet a „kockázati társadalom” fogságából való szabadulás fontosságára, a kockázatok csökkentésére irányuló társadalmi cselekvések megtételére.

Dr. Muhoray Árpád ny. pv. vezérőrnagy egyetemi docens Veszélyhelyzetben címmel a katasztrófavédelem szakmai szemléletével és tudományos alaposságával vizsgálja meg a veszélyhelyzeti tevékenységeket, mutatja be a katasztrófavédelmi szerv célirányos megelőző és beavatkozó tevékenységét. Kiemelve a várható katasztrófák prognosztizálásának a lakosság biztonsága szempontjából kiemelt fontossággal rendelkező jelentőségét.

Dr. Petrétei Dávid c. r. őrnagy egyetemi tanársegéd Maszk és karantén anyagában a világjárványt okozó kórokozó különlegességét, a vírusról szóló alapvető információkat elemezve, nemzetközi példák felvonultatásával értelmezi, miért is veszélyes a Covid-19, illetőleg azt milyen - politikai, hatalmi vagy éppen kriminalisztikai - folyamatok kísérték.

Sereg Szabolcs politológus Merre bővül az EU? című befejező fejezete szerint „Európa egysége csak kevesek álma volt, de sokak reménye lett”. Az Európai Unió történeti fejlődését követően a csatlakozás kulcsfontosságú kritériumait az értékek-alapelvek dimenziójában vizsgálja, annak nyolc stációja részletes elemzésével. Jövőbeni terveket vázol, problémákat fogalmaz meg, objektíven értékel, a balkáni térséget és a brexitet érintően elemez. A fejezet különös nóvuma az EU velünk élő valóságának relatív ismeretlensége, annak közérthető módú bemutatása.

A világ pedig nem menthetetlen, erről tanúskodnak a könyv szerzői, kijelentve annak tényét, hogy korunkban semmivel nem pótolható felelőssége van az államok vezetőinek, kiknek bölcsessége vagy belátása, együttműködési készsége sorsdöntő lehet. Tárgyalni kell, ugyanakkor erőt is kell mutatni. Egyszerre kell szövetségeket kötni és elhatárolódni. Folyamatosan választani kell jó és rossz között. Ebben lehet támasz a stabil értékrend, az érzelmi háttér, a vallásos hit és a szabad akaratból fakadó felelősségtudat, mutathatnak alternatívát Kondorosi Ferenc és Sereg András (szerk.): Noé galambja - Megjavul-e az emberiség a járvány után? nagyszerú szerzőinek rendkívül értékes tanulmányai. 
LIPPAI Zsolt: Kondorosi Ferenc - Sereg András (szerk.): Noé galambja - Megjavul-e az emberiség...

\section{FELHASZNÁLT IRODALOM}

Lippai Zsolt - Kacvinszki Blanka: A „másképp lesz holnap” ígérete. Belügyi Szemle, 69. (2021), 2. 93-104. Online: https://doi.org/10.38146/BSZ.SPEC.2021.2.5

Worldometers: Current World Population. Online: www.worldometers.info/world-population/

Worldometers: Covid-19 Coronavirus Pandemic. Online: www.worldometers.info/coronavirus/?utm_campaign=homeAdvegas1 